\title{
ANALISIS USAHA INDUSTRI RUMAHTANGGA RENGGINANG BERAS KETAN DI DESA SUMBER AGUNG KECAMATAN ARMA JAYA KABUPATEN BENGKULU UTARA
}

\author{
${ }^{1}$ Anton Feriady dan ${ }^{2}$ Wendi Rianto \\ ${ }^{1}$ Dosen Program Studi Agribisnis Fakultas Pertanian dan Peternakan \\ Universitas Muhammadiyah Bengkulu \\ 2 Alumni Program Studi Agribisnis Fakultas Pertanian dan Peternakan \\ Universitas Muhammadiyah Bengkulu \\ Koresponden e-mail: antonferiady@gmail.com
}

Penelitian ini bertujuan untuk mengetahui besarnya pendapatan, efisiensi dan tingkat kelayakan Industri Rumahtangga Rengginang Beras Ketan di Desa Sumber Agung Kecamatan Arma Jaya Kabupaten Bengkulu Utara.Penelitian ini dilaksanakan pada bulan Desember 2019 sampai dengan bulan Maret 2020 di Desa Sumber Agung Kecamatan Arma Jaya Kabupaten Bengkulu Utara.Penentuan lokasi dilakukan secara sengaja (purposive) dengan pertimbangan bahwa di desa ini merupakan penghasil rengginang beras ketan yang secara rutin memproduksi olahan rengginang beras ketan tersebut.

Metode yang digunakan dalam penelitian ini adalah metode sensus, ddengan mengambil seluruh populasi pengrajin usaha Rengginang Beras Ketan di Desa Sumber Agung Kecamatan Arma Jaya Kabupaten Bengkulu Utara.Data yang dikumpulkan dalam penelitian ini adalah data primer dan data sekunder.

Hasil analisis menunjukan bahwa pendapatan Industri Rumahtangga Rengginang Beras Ketan sebesar Rp. 1.191.829,55 Usaha Industri Rumahtangga Rengginang Beras Ketan di Desa Sumber Agung Kecamatan Arma Jaya Kabupaten Bengkulu Utara efisien karena nilai $\mathrm{R} / \mathrm{C}$ sebesar 1,47 artinya nilai $\mathrm{R} / \mathrm{C}>1$. Usaha Industri Rumahtangga Rengginang Beras Ketan di Desa Sumber Agung Kecamatan Arma Kabupaten Bengkulu Utara tidak layak karena nilai B/C sebesar 0.47 artinya nilai B/C $<1$. Serta nilai BEP produksi $71.70 \mathrm{Kg}$ dan BEP Atas Dasar Sales (Penjualan) Rp. 2.509.420,45 maka usaha ini menguntungkan dan layak untuk dilanjutkan.

\section{Kata Kunci : $\quad$ Efisiensi, Kelayakan, Rengginang}

\section{PENDAHULUAN}

\section{A. Latar Belakang}

Pangan menjadi kebutuhan primer manusia yang tidak mengenal batasan baik waktu, ruang maupun tingkatan sosial.Pangan selalu menjadi kebutuhan mendasar manusia yang tidak bisa ditawar.Demikian juga dengan strata kehidupan manusia dari kalangan atas, menengah atau bawah tidak ada yang tidak membutuhkan pangan.Yang membedahkan hanya permasalahan selera dan kebiasaan makan. Dengan kata lain pembicaraan 
tentang pangan tidak mengenal istilah out of date (usang) atau akan selalu up to date (dibutuhkan), mengingat berkaitan dengan kebutuhan pokok dan kesehatan manusia. Dengan demikian mempelajari ilmu yang berkaitan dengan pangan akan selalu menarik, bermanfaat dan sangat dibutuhkan baik bagi individu yang bersangkutan maupun bagi masyarakat luas. (Anonim, 2009 dalam Lela 2011:1).

Menurut Maimunah, (2004)

ketan merupakan salah satu varietas padi yang merupakan tumbuhan semusim. Tumbuhan ini mempunyai lidah tanaman yang panjangnya 1-4 mm dan bercangkap dua.Helaian daun berbentuk garis dengan panjang 15-80 $\mathrm{cm}$ yang tumbuh keatas dengan akar yang menggantung. Malai bang tersebut kasar.

Beras ketan adalah jenis beras yang biasanya digunakan sebagai bahan dasar makanan olahan rengginang.Beras ketan juga bisa dikonsumsi langsung setelah masak tanpa ditambah pelengkap hidangan karena rasanya yang gurih.Beras ketan kaya karbohidrat dan banyak mengandung zat tembaga yang dapat memperkuat jaringan ikat, mendukung sistem kekebalan tubuh, serta meningkatkan fungsi otak yang sehat.(Baroto, 2002).

Salah satu langkah dalam mengembangkan agroindustri khususnya di tingkat pedesaan dapat dimulai dengan melalui Usaka Mikro Kecil dan Menengah (UMKM).Salah satu peran penting Usaha Mikro Kecil dan Menengah (UMKM) dalam meningkatkan perekonomian nasional yaitu kemampuannya menciptakan lapangan kerja cukup signifikan, sektor ini memang lebih bersifat padat karya.
Peran ini tentu saja akan sangat bernilai strategis manakala masalah ini di konfrontir denganpersoalan besar yang tak kunjung dapat diatasai oleh pemerintah, yaitu pengangguran. Dengan kata lain, jika tidak adanya upaya yang serius untuk mengembangkan sektor Usaha Mikro Kecil dan Menengah (UMKM), maka dapat dipastikan pengangguran tetap akan menjadi masalah paling serius yang dihadapi oleh Indonesia di masa yang akan datang (Rifa'i, 2013).

Agroindustri adalah kegiatan yang memanfaatkan hasil pertanian sebagai bahan baku, merancang dan menyediakan peralatan serta jasa untuk kegiatan tersebut. Proses yang digunakan mencakup pengubahan dan pengawetan melalui perlakuan fisik atau kimiawi, penyimpanan, pengemasan dan distribusi. Produk agroindustri dapat merupakan produk akhir yang siap dikonsumsi ataupun sebagai produk bahan baku industri lainnya. Agroindustri merupakan komponen kedua dalam agribisnis setelah komponen produksi pertanian, komponen pengolahan ini menjadi penting karena akan meningkatnya kualitas, penyerapan tenaga kerja, keterampilan produsen dan pendapatan produsen. Mengingat jenis industri pertanian yang dapat dikembangkan sangat banyak maka perlu diprioritaskan pertumbuhan agroindustri yang mampu menangkap efek ganda yang tinggi baik bagi kepentingan pembangunan nasional, maupun pembangunan pedesaan.(Soekartawi, 2000).

Salah satu strategi yang dapat ditempuh untuk mengembangkan perekonomian daerah adalah melalui 
pengembangan agribisnis yang berwawasan kerakyatan.Secara konsepsional sistem agribisnis dapat diartikan sebagai semua aktifitas, mulai dari pengadaan dan penyaluran sarana produksi sampai dengan pemasaran produk-produk yang dihasilkan oleh usahatani yang saling terkait satu sama laiimya. Peranan agribisnis dalam peningkatan pendapatan petani sangat besar, karena didalam sistem agribisnis diutamakan keterpaduan antara empat subsistem yakni : subsistempengadaan dan penyaluran, sarana produksi usahatani atau produksi pertanian, agroindustri atau pengelolaan hasil pertanian, dan pemasaran produk pertanian.(Baharsyah, 1997).

Desa Sumber Agung merupakan salah satu desa di Kecamatan Arma
Jaya yang termasuk dalam wilayah Kabupaten Bengkulu Utara Provinsi Bengkulu. Sebagai desa yang sedang berkembang menjadi desa mandiri masyarakat tidak lagi hanya mengandalkan sektor pertanian sebagai mata pencaharian dan pendapatan masyarakat, berbagai usaha di jalani masyarakat salah satunya yaitu industri rumahtangga rengginang beras ketan yang ditekuni oleh masyarakat khusunya ibu-ibu di desa Sumber Agung, memproduksi produk olahan rengginang dari beras ketan yang mana saat ini telah menjadi produk unggulan di desa Sumber Agung Kecamatan Arma Jaya Kabupaten Bengkulu Utara. Berikut ini merupakan tabel jumlah usaha UKM dan industri rumahtangga rengginang beras ketan.

Tabel 1. Jumlah Usaha Kecil dan Menengah Kabupaten Bengkulu Utara tahun 2019

\begin{tabular}{|c|c|c|c|c|c|}
\hline & \multicolumn{5}{|c|}{ Jumlah Usaha } \\
\hline No & Kecamatan & Mikro & Kecil & Menengah & Total \\
\hline 1. & Arga Makmur & 554 & 398 & 29 & 981 \\
\hline 2. & Arma Jaya & 40 & 10 & 3 & 53 \\
\hline & Lais & 143 & 31 & 4 & 178 \\
\hline 4. & Padang Jaya & 193 & 42 & 4 & 239 \\
\hline 5. & Kerkap & 167 & 47 & 4 & 218 \\
\hline 6. & Air Besi & 129 & 28 & 3 & 160 \\
\hline 7. & Giri Mulya & 82 & 39 & 4 & 125 \\
\hline & Batik Nau & 34 & 28 & 3 & 65 \\
\hline 9. & Ketahun & 228 & 53 & 19 & 300 \\
\hline 10. & Napal Putih & 51 & 17 & 3 & 71 \\
\hline & Ulok Kupai & 144 & 10 & 4 & 158 \\
\hline & Putri Hijau & 172 & 11 & 5 & 188 \\
\hline & Air Napal & 162 & 34 & 9 & 205 \\
\hline & Hulu Palik & 47 & 6 & 3 & 56 \\
\hline 15. & Tanjung Agung Palik & 87 & 24 & 3 & 114 \\
\hline & Air Padang & 30 & 5 & 2 & 37 \\
\hline 17. & Enggano & 16 & - & - & 16 \\
\hline & Jumlah & 2279 & 783 & 102 & 3164 \\
\hline
\end{tabular}


Sumber: Dinas Koperasi dan UKM Kabupaten Bengkulu Utara (2019)

Berdasarkan tabel diatas yang diperoleh dari dinas Koperasi dan UKM di Bengkulu Utara, menunjukan bahwa di Kecamatan Arma Jaya mempunyai usaha kecil atau industri rumahtangga berjumlah 10 pengrajin yaitu usaha rumahtangga rengginang beras ketan tepatnya di desa Sumber Agung, yang mana usaha ini sangat potensial di kalangan masyarakat desa khususnya ibu-ibu. Produk olahan rengginang beras ketan tersebut sangat banyak diminati oleh masyarakat dari kalangan manapun baik didesa setempat maupun dari luar desa, usaha ini yang ditekuni oleh masyarakat sangatlah menjanjikan bagi kehidupan dimasa yang akan datang.

Rengginang adalah salah satu makanan tradisional khas Indonesia yang dibuat dari bahan beras ketan, umumnya berbentuk lingkaran dengan ukuran tertentu, berasa manis atau gurih, dan mempunyai tekstur renyah. Ada beberapa macam variasi rengginang dengan cara pembuatan yang berbeda-beda, terutama pada bumbu yang ditambahkan, bentuk, dan juga ukurannya. Meskipun demikian, secara umum proses pembuatan rengginang relatif sama atau serupa.

Usaha industri rumahtangga rengginang beras ketan di desa Sumber Agung yang mana para pengrajian memproses produksi olahan rengginang beras ketan secara rutin atau terusmenerus, maka akan ada pendapatan yang diperoleh dari setiap produksi yang dihasilkan. Namun dengan manajemennya yang sederhana produsen selama ini tidak pernah mencatat biaya-biaya yang mana biaya- biaya tersebut yaitu biaya tetap dan biaya variabel, selain itu tingkat efisiensi dan kelayakan dari suatu usaha industri rumahtangga rengginang beras ketan belum diketahui secara pasti, dengan demikian peneliti sangat tertarik ingin mengetahui usaha tersebut berapa besar pendapatannya, tingkat efisien, dan apakah sudah layak atau tidak untuk dikembangkan, selanjutnya mengetahui nilai Break Even Point (BEP) analisis ini untuk mengetahui titik pulang modal yang telah dikeluarkan usaha industri rumahtangga rengginang beras ketan pada saat itu usaha ini tidak mengalami keuntungan dan tidak juga mengalami kerugian dengan kata lain usaha industri rumahtangga rengginang beras ketan ini (impas). Berkaitan dengan uraian tersebut, topik bahasan yang akan dikaji dengan judul: "Analisis Usaha Industri Rumahtangga Rengginang Beras Ketan di Desa Sumber Agung Kecamatan Arma Jaya Kabupaten Bengkulu Utara”.

\section{B. Rumusan Masalah}

1. Berapa besar pendapatan yang diterima oleh industri rumahtangga rengginang beras ketan di Desa Sumber Agung Kecamatan Arma Jaya Kabupaten Bengkulu Utara?

2. Apakah industri rumahtangga rengginang beras ketan di Desa Sumber Agung Kecamatan Arma Jaya Kabupaten Bengkulu Utara tersebut efisien dan layak di usahakan?

3. Berapakah produksi dan nilai penjualan yang harus dihasilkan agar industri rumahtangga 
rengginang beras ketan mencapai Break Even Point(BEP) di Desa Sumber Agung Kecamatan Arma Jaya Kabupaten Bengkulu Utara?

\section{Tujuan Penelitian}

1. Untuk mengetahui besarnya pendapatan industri rumahtangga rengginang beras ketan di Desa Sumber Agung Kecamatan Arma Jaya Kabupaten Bengkulu Utara.

2. Untuk mengetahui industri rumahtangga rengginang beras ketandi Desa Sumber Agung Kecamatan Arma Jaya Kabupaten Bengkulu Utara tersebut efisien dan layak untuk dikembangkan.

3. Untuk mengetahui produksi yang harus dihasilkan dan nilai penjualan rengginang beras ketan yang diterima agar industri rumahtangga mencapai Break Even Point (BEP) di Desa Sumber Agung Kecamatan Arma Jaya Kabupaten Bengkulu Utara.

\section{METODOLOGI PENELITIAN}

Metode yang digunakan dalam penelitian ini adalah metode sensus, metode sensus adalah penentuan responden dengan mengambil seluruh anggota populasi sebagai responden.(Riduwan, 2013). Penelitian ini akan dilaksanakan di Desa Sumber Agung Kecamatan Arma Jaya Kabupaten Bengkulu Utara. Lokasi penelitian ditentukan secara sengaja (purposive).Dengan pertimbangan bahwa di desa ini merupakan penghasil rengginang beras ketan yang secara rutin memproduksi olahan rengginang beras ketan tersebut.Waktu penelitian ini dilakukan pada bulan Desember 2019 sampai dengan bulan Maret 2020.

Dalam penelitian ini yang menjadi Responden adalah pengrajin yang melakukan usaha industri rumahtangga rengginang beras ketan di Desa Sumber Agung Kecamatan Arma Jaya Kabupaten Bengkulu Utara. Dengan jumlah responden 10 orang.

Analisis data yang digunakan dalam penelitian ini adalah sebagai berikut.

1. Untuk menghitung pendapatan industri rumahtangga rengginang beras ketan digunakan, menurut Soekartawi, (2003) rumus sebagai berikut :

$$
\pi=\mathrm{TR}-\mathrm{TC}
$$

Dimana :

$$
\begin{aligned}
& \mathrm{TR}=\mathrm{Y} . \mathrm{Py} \\
& \mathrm{TC}=\mathrm{FC}+\mathrm{VC}
\end{aligned}
$$

Keterangan :

$$
\begin{aligned}
& \pi=\text { Pendapatan } \\
& \text { TR }=\text { Total Penerimaan } \\
& \text { TC }=\text { Total Biaya } \\
& \mathrm{Y}=\text { Jumlah produksi } \\
& \text { Py }=\text { Harga produk } / \mathrm{kg} \\
& \mathrm{FC}=\text { Biaya tetap } \\
& \text { VC }=\text { Biaya variabel }
\end{aligned}
$$

2. Untuk mengukur efisiensi industri rumahtangga rengginang beras ketan menggunakan analisis $\mathrm{R} / \mathrm{C}$ ratio adalah singkatan dari Revenue Cost Ratio. Menurut Soekartawi, (2003) dengan rumus sebagai berikut:

$$
\frac{R}{C} \text { Ratio }=\frac{\mathrm{TR}}{\mathrm{TC}}
$$

Dimana :

$\mathrm{TR}=$ Total Revenue (Total Penerimaan) 
$\mathrm{TC}=$ Total Cost

(Total Biaya)

Dengan kriteria :

- Jika R/C ratio < 1 maka usaha rengginang beras ketan tidak efisien.

- Jika R/C ratio> 1 maka usaha rengginang beras ketan efisien.

- Jika R/C ratio= 1 maka usaha rengginang beras ketan impas.

3. Sedangkan untuk mengetahui layak tidaknya industri rumahtangga rengginang beras ketan digunakan rumus $\mathrm{B} / \mathrm{C}$ ratio yaitu :

$$
\frac{B}{C} \text { Ratio }=\frac{\mathrm{TR}-\mathrm{TC}}{T C}
$$

Dimana :

$$
\begin{aligned}
& \mathrm{B} / \mathrm{C}=\text { benefit /cost } \\
& \text { ratio } \\
& \mathrm{TR}=\text { Total revenue } \\
& \mathrm{TC}=\text { Total cost }
\end{aligned}
$$

Dengan kriteria :

- Jika $\mathrm{B} / \mathrm{C}$ ratio $\geq 1$ maka usaha rengginang beras ketan tersebut layak untuk diusahakan.

- Jika B/C ratio $\leq 1$ maka usaha rengginang beras ketan tersebut tidak layak diusahakan.

4. Sedangkan untuk Analisis Break Even Point (BEP) atau titik impas pada industri rumahtangga rengginang beras ketan, diukur dengan menggunakan rumus sebagai berikut:

a. BEP Produksi

$$
\mathrm{BEP}=\frac{\text { Total Cost }(\mathrm{TC})}{\operatorname{Harga}(\mathrm{P})}
$$

b. BEP Atas Dasar Sales (Penjualan)

$\mathrm{BEP}=$ Volume Penjualan $(\mathrm{Q}) \mathrm{x}$ Harga (P)

Dimana:

BEP : Break Even Point

TC : Total Biaya (Biaya Tetap + Biaya Variable)

P : Harga Rata-rata pada saat produksi

Q : Jumlah Produksi Rengginang Pada Sudah BEP)

\section{HASIL DAN PEMBAHASAN}

\section{Identitas Responden}

Identitas responden yang diamati dalam penelitian ini meliputi yaitu : umur, tingkat pendidikan, tanggungan keluarga, serta pengalaman berusaha industri rumahtangga.

\section{Umur}

Karakteristik umur pengrajin rengginang beras ketan berkisar antara 34 tahun sampai dengan 58 tahun. Umur pengrajin rengginang beras ketan dapat dilihat pada tabel berikut:

Tabel 2. Distribusi Umur Responden

\begin{tabular}{cccc}
\hline No & Interval (tahun) & $\begin{array}{c}\text { Jumlah Responden } \\
\text { (orang) }\end{array}$ & Persentase (\%) \\
\hline$(1)$ & $(2)$ & $(3)$ & $(4)$ \\
\hline 1 & $34-37$ & 2 & 20 \\
2 & $38-48$ & 3 & 30 \\
3 & $49-55$ & 3 & 30 \\
4 & $56-58$ & 2 & 20 \\
\hline Jumlah & & 10 & 100 \\
\hline
\end{tabular}


Sumber: Data primer diolah tahun 2020

Berdasarkan tabel di atas dapat dilihat bahwa jumlah pengrajin industri rumahtangga rengginang beras ketan adalah 10 orang. Menurut hasil riset bahwa usia produktif itu mulai dari 18 tahun sampai dengan 50 tahun (Marinki, 2008). Ini berarti seluruh pengrajin rengginang beras ketan yang ada di desa Sumber Agung Kecamatan Arma Jaya Kabupaten Bengkulu Utara, rata-rata berada pada usia produktif sehingga pengrajin bekerja secara optimal untuk mengolah dan menjalankan usahanya.

\section{Pendidikan}

Pendidikan dianggap sebagai salah satu sarana untuk memajukan dan membangun masyarakat. Tingkat pendidikan pengrajin rengginang beras ketan dalam penelitian ini dapat dilihat pada tabel berikut:

Tabel 3. Keadaan Pendidikan Formal Responden Pengrajin Rengginang Beras Ketan di Desa Sumber Agung Kecamatan Arma Jaya Kabupaten Bengkulu Utara

\begin{tabular}{cccc}
\hline No & Tingkat Pendidikan & $\begin{array}{c}\text { Jumlah Responden } \\
\text { (Orang) }\end{array}$ & Persentase (\%) \\
\hline$(1)$ & $(2)$ & $(3)$ & $(4)$ \\
\hline 1 & Tamat SD & 6 & 60 \\
2 & Tamat SMP & 2 & 20 \\
3 & Tamat SMA & 2 & 20 \\
\hline Jumlah & & 10 & 100 \\
\hline
\end{tabular}

Sumber: Data primer diolah tahun 2020

Berdasarkan tabel diatas menunjukan bahwa pengrajin rengginang beras ketan berpendidikan formal terbanyak adalah pendidikan SD yaitu sebanyak 6 orang (60\%). Dengan latar belakang pendidikan formal SD, maka diperlukan tambahan pendidikan non formal seperti penyuluhan pertanian dan pelatihanpelatihan yang dilakukan instansi pemerintahan kepada pengrajin rengginang beras ketan supaya bisa meningkatkan wawasan dan menambah ilmu bagi masyarakat cara pengelolahan yang lebih baik lagi.

\section{Jumlah Tanggungan Keluarga}

Tanggungan keluarga disini adalah semua orang yang tinggal bersama pengrajin rengginang beras ketan atau tidak tinggal bersamanya tetapi hidupnya masi dibiayai oleh pengelolah tersebut. Jumlah tanggungan keluarga pengrajin rengginang beras ketan dapat dilihat pada tabel dibawah ini: 
Tabel 4. Jumlah Tanggungan Pengrajin Rengginang Beras Ketan di Desa Sumber Agung Kecamatan Arma Jaya Kabupaten Bengkulu Utara

\begin{tabular}{cccc}
\hline No & $\begin{array}{c}\text { Jumlah Tanggungan } \\
\text { Keluarga (Jiwa) }\end{array}$ & $\begin{array}{c}\text { Jumlah Responden } \\
\text { (Orang }\end{array}$ & Persentase (\%) \\
\hline$(1)$ & $(2)$ & $(3)$ & $(4)$ \\
\hline 1 & 2 & 2 & 20 \\
2 & 3 & 3 & 30 \\
3 & 4 & 3 & 30 \\
4 & 5 & 2 & 20 \\
\hline Jumlah & & 10 & 100 \\
\hline
\end{tabular}

Sumber: Data primer diolah tahun 2020

Berdasarkan tabel diatas dapat dilihat bahwa pengolah rengginang beras ketan yang paling banyak adalah memiiki tanggungan 5 jiwa, yaitu sebanyak 2 orang atau (20\%) banyaknya tanggungan keluarga yang menjadi beban ekonomi bagi pengrajin rengginang beras ketan ini akan mendorong pengolah meningkatkan produksinya dengan mengolah usahanya secara optimal.

\section{Pengalaman Usaha}

Selain pendidikan, pengalaman seseorang juga sangat menentukan di dalam keberhasilan dalam melakukan suatu usaha. Semakin lama orang tersebut melakukan usahanya maka akan semakin tahulah ia akan kelemahan usahanya, sehingga ia akan mencari jalan alternatif untuk meningkatkan produksinya. Pengalaman usaha pengrajin rengginang beras ketan di desa Sumber Agung dapat dilihat pada tabel berikut:

Tabel 5. Pengalaman Usaha Pengrajin Rengginang Beras Ketan di Desa Sumber Agung Kecamatan Arma Jaya Kabupaten Bengkulu Utara

\begin{tabular}{cccc}
\hline No & $\begin{array}{c}\text { Lama Usahanya } \\
\text { (Tahun) }\end{array}$ & $\begin{array}{c}\text { Jumlah Pengrajin } \\
\text { (Orang) }\end{array}$ & Persentase (\%) \\
\hline$(1)$ & $(2)$ & $(3)$ & $(4)$ \\
\hline 1 & $3-4$ & 2 & 20 \\
2 & $5-6$ & 3 & 30 \\
3 & $7-8$ & 5 & 50 \\
\hline Jumlah & & 10 & 100 \\
\hline
\end{tabular}

Sumber: Data primer diolah tahun 2020

Berdasarkan dari tabel diatas bahwa pengrajin rengginang beras ketan yang mempunyai pengalaman usaha terbesar adalah selama 7-8 tahun, yaitu sebanyak 5 orang $(20 \%)$ dari jumlah pengrajin yang ada. Pengrajin rengginang beras ketan yang berpengalaman selama 3-4 tahun sebanyak $2(20 \%)$ orang dan yang 5-6 tahun ada sebanyak 3 orang (30\%). 


\section{Analisis Biaya Produksi Rengginang Beras Ketan}

Biaya produksi industri rumahtangga rengginang beras ketan merupakan biaya yang dikeluarkan oleh pengrajin dalam melakukan kegiatan usaha rengginang beras ketan, biaya produksi terdiri dari biaya tetap dan biaya variabel.

\section{Biaya Tetap (Fixed cost) \\ Biaya Penyusutan Alat}

Peralatan yang digunakan dalam usaha industri rumahtangga rengginang beras ketan yang tidak habis dipakai dalam satu kali proses produksi dihitung biaya penyusutannya. Biaya peyusutan peralatan yang dihitung adalah semua peralatan yang dipakai oleh pengrajin rengginang beras ketan, peralatan yang digunakan dalam pembuatan rengginang beras ketan ini meliputi:

Dandang, baskom, gedok bambu, tirisan, cetakan, centong kayu, tungku, staples. Biaya penyusutan peralatan usaha industri rumahtangga rengginang beras ketan di Desa Sumber Agung Kecamatan Arma Jaya Kabupaten Bengkulu Utara rata-rata sebesar. Rp. 4.314,72 per periode dari total biaya yang dikeluarkan.

\section{Sewa Tempat}

Sewa tempat yang dibayarkan dalam kegiatan usaha industri rumahtangga rengginang beras ketan ini adalah tempat yang digunakan sebagai tempat berproduksi, yaitu dapur yang berada di rumah masing-masing responden.Biaya sewa tempat yang digunakan untuk berproduksi dalam usaha industri rumahtangga rengginang beras ketan di Desa Sumber Agung
Kecamatan Arma Jaya Kabupaten Bengkulu Utara rata-rata sebesar Rp. $61.739,73$ per periode dari total biaya yang dikeluarkan.

Berdasarkan hasil penelitian bahwa jumlah biaya tetap usaha industri rumahtpangga rengginang beras ketan di Desa Sumber Agung Kecamatan Arma Jaya Kabupaten Bengkulu Utara yang dikeluarkan rata-rata sebesar Rp. 66.054,45.

\section{Biaya Variabel (Variabel Cost)}

A. Biaya Bahan Baku dan Bahan Lain

Biaya bahan baku dan biaya bahan lain dalam usaha industri rumahtangga rengginang beras ketan di Desa Sumber Agung Kecamatan Arma Jaya Kabupaten Bengkulu Utara untuk memproduksi antara lain yaitu : Beras ketan, bawang putih, masako, garam, pelastik kemasan, isi staples, lebel produk, kayu bakar. Rata-rata pembelian input produksi yaitu sebesar Rp. 2.362.791,00 / Bulandari total biaya yang dikeluarkan.

\section{B. Biaya Tenaga Kerja}

Tenaga kerja yang digunakan dalam pengolahan usaha industri rumahtangga rengginang beras ketan di Desa Sumber Agung Kecamatan Arma Jaya Kabupaten Bengkulu Utara terdiri dari laki-laki, perempuan, dan anakanak baik dari dalam keluarga dan dari luar keluarga.Biaya tenaga kerja pengolahan rengginang beras ketan ratarata sebesar Rp. 80.575,00.

Adapun untuk lebih jelasnya rincian biaya-biaya yang digunakan dalam usaha industri rumahtangga rengginang beras ketan disajikan dalam tabel dibawah ini: 
Tabel 6.Rata-rata Total Biaya Usaha Idustri Rumahtangga Rengginang Beras Ketan

\begin{tabular}{|c|c|c|}
\hline No & Uraian & Biaya (Rp) \\
\hline (1) & (2) & (3) \\
\hline \multirow[t]{4}{*}{1} & A. Biaya Tetap & \\
\hline & $>$ Sewa Tempat & $61,739.73$ \\
\hline & $>$ Penyusutan Alat & $4,314.72$ \\
\hline & Jumlah Biaya Tetap & $66,054.45$ \\
\hline \multirow[t]{14}{*}{2} & B. Biaya Variabel & \\
\hline & $>$ Bahan Baku & \\
\hline & $>$ Beras Ketan & $1,922,880.00$ \\
\hline & $>$ Bawang Putih & $3,669.00$ \\
\hline & $>$ Masako & $16,600.00$ \\
\hline & $>$ Garam & $2,492.00$ \\
\hline & $>$ Bahan Lain & \\
\hline & $>$ Plastik Kemasan & $262,790.00$ \\
\hline & $>$ Isi Staples & $17,290.00$ \\
\hline & $>$ Lebel Produk & $11,470.00$ \\
\hline & $>$ Kayu Bakar & $125,600.00$ \\
\hline & $>$ Tenaga Kerja (HKSP) & $80,575.00$ \\
\hline & Jumlah Biaya Variabel & $2,443,366.00$ \\
\hline & Biaya Total $(\mathrm{FC}+\mathrm{VC})$ & $2,509,420.45$ \\
\hline
\end{tabular}

Sumber: Data primer diolah tahun 2020

Berdasarkan tabel diatas diketahui bahwa total biaya yang dikeluarkan oleh usaha industri rumahtangga rengginang beras ketan di Desa Sumber Agung Kecamatan Arma Jaya Kabupaten Bengkulu Utara dengan biaya rata-rata sebesar Rp. 2.509.420,45 / Bulan dan biaya yang paling besar dikeluarkan adalah biaya variabel yaitu rata-rata sebesar Rp. 2.443.366,00 total biaya merupakan penjumlahan biaya tetap (FC) dan biaya variabel (VC) dimana biaya tetap merupakan penjumlahan antara sewa tempat, penyusutan alat dan biaya variabel adalah penjumlahan dari biaya bahan baku, bahan lain, dan tenaga kerja.

Pembahasan Usaha Industri Rumahtangga Rengginang Beras Ketan

Penerimaan Rengginang Beras Ketan Penerimaan merupakan nilai dari total produksi usaha pengrajin dan merupakan pendapatan kotor. Penerimaan usaha Industri Rumahtangga Rengginang Beras Ketan adalah hasil produksi dikalikan dengan harga jual yang diterima oleh pengrajin. Rata-rata penerimaan usaha rengginang 
beras ketan dapat dilihat pada tabel dibawah ini:

Tabel 7. Rata-rata penerimaan Usaha Industri Rumahtangga Rengginang Beras Ketan

\begin{tabular}{ccccc}
\hline No & Uraian & $\begin{array}{c}\text { Total } \\
\text { Produksi/Kg }\end{array}$ & Harga (Rp) & $\begin{array}{c}\text { Penerimaan } \\
(\mathrm{Rp})\end{array}$ \\
\hline$(1)$ & $(2)$ & $(3)$ & $(4)$ & $(5)$ \\
\hline Rata-rata & $\begin{array}{c}\text { Rengginang Beras } \\
\text { Ketan }\end{array}$ & 105.75 & $35,000.00$ & $3.701 .250,00$ \\
\hline
\end{tabular}

Sumber: Data primer diolah tahun 2020

Berdasarkan tabel diatas diketahui bahwa rata-rata penerimaan usaha industri rumahtangga rengginang beras ketan di desa Sumber Agung Kecamatan Arma Jaya Kabupaten Bengkulu Utara adalah sebesar Rp. 3.701.250,00 / Bulan dengan produksi rata-rata rengginang beras ketan sebanyak $105.75 \mathrm{Kg}$ dan harga yang diterima pengrajin sebesar Rp. $35,000.00$.

\section{PendapatanRengginang Beras Ketan}

Pendapatan merupakan hasil dari total penerimaan (TR) dikurangi dengan total biaya (TC).Pendapatan pada usaha industri rumahtangga rengginang beras ketan ini dapat diperoleh dari selisih antara biaya yang dikeluarkan dengan penerimaan yang diperoleh pengrajin, apabila nilai selisih tersebut positif maka dapat dikatakan usaha indutri rumahtangga rengginang beras ketan ini menguntungkan. Besar nya pendapatan ditentukan oleh besarnya penerimaan dan biaya yang dikeluarkan oleh pengrajin rengginang beras ketan di Desa Sumber Agung, untuk lebih jelasnya pendapatan yang diterima pengrajin dapat dilihat pada tabel berikut:

Tabel 8. Rata-rata Pendapatan Usaha Rengginang Beras Ketan

\begin{tabular}{ccccc}
\hline No & Uraian & $\begin{array}{c}\text { Penerimaan } \\
(\text { TR })\end{array}$ & $\begin{array}{c}\text { Total Biaya } \\
(\text { TC) }\end{array}$ & Pendapatan (Rp) \\
\hline$(1)$ & $(2)$ & $(3)$ & $(4)$ & $(5)$ \\
\hline Rata-rata & $\begin{array}{c}\text { Rengginang Beras } \\
\text { Ketan }\end{array}$ & $3.701 .250,00$ & $2.509 .420,45$ & $1.191 .829,55$ \\
\hline
\end{tabular}

Sumber: Data primer diolah tahun 2020 
Berdasarkan tabel diatas dapat diketahui bahwa rata-rata pendapatan usaha industri rumahtangga rengginang beras ketan di Desa Sumber Agung Kecamatan Arma Jaya Kabupaten Bengkulu Utara rata-rata sebesar Rp. 1.191.829,55 / Bulan artinya hasil usaha ini menguntungkan karena hasil pendapatan tidak negatif. Bila sebaliknya apabila nilai yang diterima pengrajin maka usaha ini mengalami kerugian.

Sejalan dengan penelitian yang dilakukan oleh Pusat Penelitian Dan Pengembangan Teknologi Pangan Institut Pertanian Bogor (1981) tentang analisis Industri Pangan Untuk Pedesaan (rengginang beras ketan).Usaha ini dapat memberikan pendapatan pada pengrajin sebesar Rp. $62.458,00$ per periode.Artinya usaha pengrajin rengginang ini telah di jalani sejak dulu karna usaha ini memberikan suatu keuntungan.

\section{Efisiensi Usaha}

Efisiensi merupakan hasil perbandingan output dengan input. Semakin tinggi rasio output terhadap input maka semakin tinggi tingkat efisiensi, efisiensi dapat pula mencerminkan keuntungan yang diterima pengrajin semakin besar efisiensi maka semakin besar pula keuntungan yang diperoleh. R/C Ratio yang diterima adalah:

$$
\begin{gathered}
\frac{\mathrm{R}}{\mathrm{C}} \text { Ratio }=\frac{\mathrm{TR}}{\mathrm{TC}} \\
\frac{\mathrm{R}}{\mathrm{C}} \text { Ratio }=\frac{3.701 .250,00}{2.509 .420,45}=1,47
\end{gathered}
$$

Berdasarkan angka diatas menunjukan bahwa nilai R/C Ratio yang didapat dalam usaha industri rumahtangga rengginang beras ketan adalah sebesar 1,47 artinya setiap mengeluarkan biaya 1 rupiah maka akan mendapatkan penerimaan sebesar 1,47 Dengan demikian dari segi efisiensi usaha bahwausaha industri rumahtangga rengginang beras ketan di Desa Sumber Agung Kecamatan Arma Jaya Kabupaten Bengkulu Utara sudah efisien, karena nilai R/C Ratio> 1. Agar usaha industri rumahtangga rengginang beras ketan ini lebih efisien atau memperoleh keuntungan yang lebih besar maka proporsi terimaan harus lebih tinggi dibandingkan dengan biaya yang dikeluarkan.

Sejalan dengan penelitian yang dilakukan oleh Endang Tri Wahyuni dan Suryo Ediyono tentang Analisis Efisiensi Agroindustri Rengginang di Desa Pademawu Kecamatan Pademawu Kabupaten Pamekasan Madura terjadi peningkatan R/C Ratio sebesar 1.08.

\section{Kelayakan Usaha}

Suatu usaha dapat dikatakan layak apabila B/C Ratio> 1 dan dikatakan tidak layak apabila B/C Ratio< 1. Untuk mengetahui layak tidaknya usaha industri rumahtangga rengginang beras ketan di Desa Sumber Agung, di hitung dengan menggunakan rumus berikut:

$$
\begin{aligned}
& \frac{\mathrm{B}}{\mathrm{C}} \text { Ratio }=\frac{\mathrm{TR}-\mathrm{TC}}{\mathrm{TC}} \\
& \frac{\mathrm{B}}{\mathrm{C}} \text { Ratio } \\
& =\frac{3.701 .250,00-2.509 .420,45}{2.509 .420,45} \\
& =0,47
\end{aligned}
$$

Berdasarkan hasil penelitian yang diperoleh bahwa nilai $\mathrm{B} / \mathrm{C}$ Ratio sebesar 0,47 artinya setiap 1 rupiah yang dikeluarkan maka akan memberikan keuntungan sebesar 0,47 dari segi kelayakan usaha maka usaha rengginang beras ketan ini adalah tidak 
layak karena nilai B/C Ratio $<1$. Usaha industri rumahtangga rengginang beras ketan di Desa Sumber Agung Kecamatan Arma Jaya Kabupaten Bengkulu Utara ini bisa di usahakan dalam jangka waktu panjang.Ketidak layakan ini disebabkan karena keuntungan yang diperoleh lebih kecil dari biaya yang dikeluarkan dan untuk analisis perhitungan dalam penelitian ini menggunakan analisis secara bisnis dalam suatau usaha, yaitu menghitung sewa tempat, penyusutan alat, dan tenaga kerja dalam pengolahan rengginang beras ketan.

Sejalan dengan penelitian yang dilakukan oleh Nora Ariska (2018) tentang analisis kelayakan usaha kue grieng (rengginang beras ketan) di Desa Cot Batee Kecamatan Kuala Kabupaten Bireuen memberikan peningkatan nilai B/C Ratiosebesar 0.67 artinya usaha tersebut tidak layak tetapi masi bisa tetap dijalankan karena usaha ini hanya sampingan saja oleh pengrajin, disisi lain masih ada pemasukan, untuk mencukupi biaya hidup kedepan pengrajin adalah seorang buruh tani.

Analisis Break Even Point (BEP)

\section{Break Even Point (BEP)}

merupakan suatu keadaan perusahaan dimana jumlah total penghasilan besarnya sama dengan jumlah total biaya $\quad($ TR-TC $=0)$ atau suatu keadaan dimana dalam kondisi ini suatu usaha yang dilakukan tidak mendapatkan keuntungan dan tidak mengalami kerugian (impas). Untuk melihat Break Event Poin (BEP) atau titik pulang pokok usaha industri rumahtangga rengginang beras ketan di Desa Sumber Agung Kecamatan Arma Jaya Kabupaten Bengkulu Utara, jumlah rengginang beras ketan yang harus dihasilkan agar mencapai Break Even Point:

a. BEP Produksi:

$$
\begin{gathered}
\text { BEP }=\frac{2.509 .420,45}{35.000,00} \\
=71.70 \mathrm{Kg} \\
\text { b. Sedangkan BEP Atas Dasar } \\
\text { Sales (Penjualan): } \\
\text { BEP }=71.70 \times 35.000,00 \\
=\text { Rp. } 2.509 .420,45
\end{gathered}
$$

Berdasarkan hasil penelitian dapat diketahui bahwa jumlah produksi dan nilai penjualan tersebut, akan dapat menutupi biaya tetap dan biaya variabel yang harus dikeluarkan oleh pengrajin regginang beras ketan. Dengan demikian pada saat BEP produksi sebesar $71.70 \mathrm{Kg}$ dan volume penjualan atau penerimaan yang diteima pengrajin sebesar Rp. 2.509.420,45 maka industri rumahtangga rengginang beras ketan di Desa Sumber Agung Kecamatan Arma Jaya Kabupaten Bengkulu Utara berada pada titik impas $(\mathrm{TR}-\mathrm{TC}=0)$ atau sudah mencapai BEP. Sehingga dengan produksi rata-rata sebesar $105.75 \mathrm{Kg}$ artinya usaha industri rumahtangga rengginang beras ketan telah melebihi titik impas dengan kata lain memperoleh keuntungan atau usaha industri rumahtangga rengginang beras ketan di Desa Sumber Agung Kecamatan Arma Jaya Kabupaten Bengkulu Utara layak untuk dilanjutkan.

\section{KESIMPULAN DAN SARAN}

\section{Kesimpulan}

Berdasarkan hasil penelitian dan pembahasan dapat disimpulkan sebagai berikut:

1. Pendapatan usaha industri rumahtangga rengginang beras 
ketan di Desa Sumbr Agung Kecamatan Arma Jaya Kabupaten Bengkulu Utara memberikan keuntungan rata-rata sebesar $\mathrm{Rp}$. 1.191.829,55 / Bulan.

2. Usaha rengginang beras ketan di Desa Sumber Agung Kecamatan Arma Jaya Kabupaten Bengkulu Utara sudah efisien karena nilai R/C Ratio $>1$ yaitu sebesar 1,47.

3. Usaha rengginang beras ketan di Desa Sumber Agung Kecamatan Arma Jaya Kabupaten Bengkulu Utara tidak layak karena nilai B/C Ratio yang diperoleh sebesar 0,47 artinya nilai $\mathrm{B} / \mathrm{C}$ Ratio $<1$.

4. Usaha rengginang beras ketan di Desa Sumber Agung Kecamatan Arma Jaya Kabupaten Bengkulu Utara jumlah BEP produksi 71.70 $\mathrm{Kg}$ dan BEP Atas Dasar Sales (Penjualan) Rp. 2.509.420,45.

\section{Saran}

Berdasarkan uraian diatas, maka dapat disarankan:

1. Bahwa produksi rengginang beras ketan per bulan perlu ditingkatkan lagi agar pendapatan dapat meningkat.

2. Masi sangat perlu pembinaan secara kontiyu dari pemerintahan terhadap pengrajin rengginang beras ketan tersebut.

3. Perlu dilakukan pengemasan yang lebih menarik lagi agar jumlah penerimaan bisa lebih meningkat.

\section{DAFTAR PUSTAKA}

Alfantri, R. 2011. Analisis Pendapatan Dan Efisiensi Industri Rumahtangga Keripik Ubi Jalar Di Desa Parda Suka Kecamatan
Maje Kabupaten Kaur. Skripsi Mahasiswa Fakultas Pertanian Universitas Muhammadiyah Bengkulu. Dipublikasikan).

(Tidak

Achmad, S. D. 1989. Ilmu Gizi Untuk Mahasiswa dan Frofesi, Jilid 1, Jakarta: Daian Rakyat.

Baroto, T. (2002).Perencanaan dan Pengendalian Produksi. Ghalia, Jakarta.

Baharsyah, S. 1992. Sambutan Mentri Muda Pertanian Selaku Ketua PERHEPI Pada Sminar Nasional di Pekanbam.

Joesron, S. dan Fathorrozi.2003.Teori Ekonomi Mikro. Salemba Empat. Jakarta.

Kasmir, 2006.Manajemen Perbankan. Jakarta: Radja Grafindo Persada.

Lla, M. 2011. Analisa Usaha Rengginang Ubi Kayu Pada Industri Rumah Tangga "Bunga" Di Desa Sido Mukti Kecamatan Padang Jaya Kabupaten Bengkulu Utara. Skripsi Mahasiswa Fakultas Pertanian Universitas Muhammadiyah Bengkulu. (Tidak Dipublikasikan).

Maimunah, S. 2004. Pengaruh Variasi Dosis Ragi Dan Lama Fermentasi Terhadap Kadar Glukosa Dan Kadar Alkohol Pada Tape Ketam Hitam, Skripsi Tidak Diterbitkan, Malang : F. MIPA Jurusan Biologi Universitas Islam Negeri Malang.

Mariani, L. 2013. Analisis Pendapatan Industri RumahTangga Usaha Pembuatan Tahu Di Gampong Purworejo Kecamatan Kuala 
Kabupaten Nagan Raya.

Universitas Teuku Umar

Meulaboh, Aceh Barat.

Mubyarto, 2003.Pengantar Ekonomi Pertanian. Edisi Ketiga. Jakarta. (ID): LP3ES.

Marinki, 2008. Usia Produktif.

Http://Marinki.Blogdetik.Com/20 08/12/02/Usia Produktif diakses 03 Januari 2011.

Priyanto, T. 2012. Beras Ketan \& Sifat Fisika-Kimianya.

http://www.alatcetakrengginang.com/20 $\underline{12 / 02 / \text { beras-ketan-sifat-fisika- }}$ kimianya.html. 12 mei 2013.

Ridwan, M. 1998. Biaya-Biaya Produksi.Edisi Revisi, Penebar Swadaya. Jakarta.

Riyanto, B. 2001.DasardasarPembelanjaan Perusahaan Edisi IV.BPFE.Yogyakarta.

Riduwan, 2013.Dasar-dasar statistika.Alfabeta. Bandung.

Rifa'i, B. 2013.Efektivitas Pemberdayaan Usaha Mikro Kecil dan Menengah (UMKM) Krupuk Ikan dalam Program Pengembangan Labsite Pemberdayaan Masyarakat Desa Kedung Rejo Kecamatan Jabon Kabupaten Sidoarjo.Jurnal Kebijakan dan Manajemen Publik Vol. 1 No. 1.Januari 2013.FSIP Universitas Airlangga.

Soekartawi, 2000.Pengantar Teori Agroindustri. PT. Raja Grafindo Persada. Jakarta.

2005. Agribisnis Teori dan Aplikasi.Jakarta.
1995. Analisis Usahatani. UIPress. Jakarta.

2006. Analisis Usaha
tani.Penerbit $\begin{aligned} & \text { Universitas } \\ & \text { Indonesia. } \\ & \text { Halaman. }\end{aligned}$

Sumaatmadja, 1998.Pendekatan dan Analisa Keuangan.ITB. Bandung.

Samsudin, A.M. dan Khoiruddin. 2009. Ekstraksi, Filtrasi Membran dan Uji Stabilitas Zat Warna dari Kulit Manggis (Garcinia mangostana). Jurusan TeknikKimia Fakultas Teknik. Universitas Diponegoro. Semarang.

Sukirno, S. 2005. Mikro Ekonomi Teori Pengantar. Edisi Ketiga. Raja Grafindo Persada. Jakarta.

Yanuar, 2009.Potensi Kulit Jeruk Sebagai Bahan Pengurai Pada Proses Pengolahan Limbah Kantong Plastik. IPB: Bogor.

Zulkobri, 2007.Analisis Break Even Point (BEP) Pada Usaha Pembibitan Karet di Kecamatan Lubuk Linggau Selatan 1 Kota Lubuk Linggau. Skripsi Mahasiswa Fakultas Pertanian Universitas Muhammadiyah Bengkulu. (Tidak Dipublikasikan). 
